\title{
BREAKFAST CONSUMPTION PATTERNS, KNOWLEDGE, ATTITUDE, PRACTICE AND BARRIERS AMONG MALAYSIAN UNIVERSITY STUDENTS
}

\author{
SIVAGAMI JAYAVELOO ${ }^{1}$, NORLIDA MAT DAUD ${ }^{1,2^{*}}$ and HAFEEDZA ABDUL RAHMAN ${ }^{1,2}$ \\ ${ }^{1}$ Department of Food Sciences, Faculty of Science and Technology, \\ Universiti Kebangsaan Malaysia, 43600 Bangi, Selangor, Malaysia \\ ${ }^{2}$ Innovation Centre for Confectionery Technology (MANIS), \\ Faculty of Science and Technology, Universiti Kebangsaan Malaysia, \\ 43600 Bangi, Selangor, Malaysia \\ *E-mail: norlida.daud@ukm.edu.my
}

Accepted 19 June 2021, Published online 30 June 2021

\begin{abstract}
Breakfast is the most important meal of the day. However, university students tend to skip breakfast due to their hectic lifestyles. Therefore, the patterns, knowledge, attitude, practice (KAP), and barriers of breakfast consumption were investigated in this study via questionnaires among 396 students of Universiti Kebangsaan Malaysia. Results showed that only $35.9 \%$ of students had breakfast between 6 to 7 days per week. Chinese students had a significantly higher $(p<0.001)$ breakfast consumption compared with other groups. These results were consistent with the KAP scores in which Chinese students had the highest scores compared to their counterparts. However, the overall KAP scores were still at moderate levels with significant $(p<0.001)$ positive correlations were found between knowledge and attitude $(r=0.421)$, knowledge and practice $(r=0.166)$, and attitude and practice $(r=0.443)$. Malay students acknowledged the high cost of breakfast as a significant $(p=0.03)$ barrier for breakfast consumption compared to other groups. No significant difference $(p>0.05)$ was shown in other parameters. In conclusion, the frequency of breakfast consumption among the students was still low. The focus should be emphasized on practical strategies to address the barrier and encourage behavioral change for the students.
\end{abstract}

Key words: Attitude, barriers, breakfast consumption, knowledge, practice, university students

\section{INTRODUCTION}

Healthy eating habit is extremely crucial and breakfast has been considered as an important dietary factor for energy regulation. However, according to Pendergast et al. (2016), breakfast is more commonly missed compared to other meals. Various studies have reported that skipping breakfast has been linked with the risk of mortality from cardiovascular disease (Chen et al., 2020), cancer (Yokoyama et al., 2016), diabetes (Ballon et al., 2019), and obesity (Ma et al., 2020). For university students, breakfast consumption is associated with a range of positive outcomes, including better academic performance (Javaid, 2020; Pengpid \& Peltzer, 2020), vitamins and minerals intake (Sangwanna \& Thongprasert, 2019), physical performance (Najwa \& Appukutty, 2018) and ideal

\footnotetext{
* To whom correspondence should be addressed.
}

body weight (Mansouri et al., 2020). Consistent breakfast consumption is considered a healthy eating habit that will help students in improving their cognitive function (Brandley \& Holton, 2020). Pedersen et al. (2013) reported that adolescents who had low frequencies of breakfast consumption at the age of 15 years old would still have low breakfast consumption during young adulthood, 19 and 27 years old. Indeed, Pendergast et al. (2016) reported that breakfast is the least consumed meal (14-88\%) compared to lunch (8-57\%) and dinner (4-57\%) among people aged between 18 to 30 years old.

More importantly, there is much evidence that shows the relationship between the low frequencies of breakfast consumption with higher body mass index (BMI) (Mathiyalagen et al., 2019; Ma et al., 2020; Mansouri et al., 2020; Wicherski et al., 2021). In addition to weight management, breakfast consumption has also been positively correlated with most micronutrients, including vitamin $\mathrm{B}_{12}, \mathrm{C}, \mathrm{D}$, 
folate, iron, iodine, magnesium, vitamin A, calcium, and dietary fiber, and negatively correlated with dietary fats, sodium and added sugar (Fayet-Moore et al., 2017; Pereira et al., 2018; Ramsay et al., 2018; Gaal et al., 2018). Therefore, individuals who skip breakfast would not be able to have optimal nutrient intake and potentially expose themselves to unhealthy metabolic conditions. Furthermore, skipping breakfast has also been closely associated with unhealthy lifestyles, which include poor food choices and a lack of physical activities among university students (Pengpid \& Peltzer, 2020).

University students, particularly first-year students experience significant changes from living under the supervision and care of parents to independent living on their own. In addition, to adapt to an independent life, they are also searching for self-reliance, including finding the dietary lifestyle that fits them (Das \& Evans, 2014). Thus, students are more likely to practice unhealthy eating habits (Tok et al., 2018; Bede et al., 2020). A study conducted among Italian university students showed that students who lived with their parents had a healthy diet and more exercise than students who lived alone (Lupi et al., 2015). Many factors influence breakfast consumption among university students. However, lack of time to prepare or eat breakfast has been identified as the primary factor (Pendergast et al., 2016; Awang Damit et al., 2019; Chawla et al., 2019; Javaid, 2020) Additionally, lack of appetite, not hungry and weight control were few of the reasons of breakfast skipping (Pendergast et al., 2016; Chawla et al., 2019; Javaid, 2020).

To date, a few studies have investigated the role of breakfast consumption on academic performance (Chawla et al., 2019), its association with snacking behavior (Isa \& Masuri, 2011), and BMI (Isa \& Masuri, 2011; Sundaram et al., 2018), and breakfast skipping and its associated factors (Moy et al., 2009) among Malaysian university students. However, no studies have looked into the knowledge, attitude, practice (KAP), and barriers of breakfast consumption among them. Assessment of these parameters is needed as it would help to identify gaps in KAP between the races and evaluate information between what is said (from knowledge and attitudes) and what is done (practice). Possible factors and reasons for their attitudes towards breakfast consumption can also be determined. In the future, this information can be used to design specific interventional strategies in increasing awareness and optimizing breakfast consumption tailored to the needs of Malaysian university students. Therefore, this study was conducted to determine the breakfast consumption patterns, KAP, and barriers for students to optimize their breakfast consumption.

\section{MATERIALS AND METHODS}

\section{Subject selection and sampling procedure}

This cross-sectional study was conducted among 396 students of Universiti Kebangsaan Malaysia (UKM), Bangi, Selangor, Malaysia, comprised of 132 Malay, Chinese, and Indian, respectively. The population size was based on the 2017 UKM student population of 22540 people. The sampling size was calculated according to the formula by Krejcie and Morgan $(1970), n=\left[\left(X^{2}\right)(N)(P)(1-P) /\right.$ $\left.\left(d^{2}\right)(N-1)\right]+\left[\left(X^{2}\right)(P)(1-P)\right]$ in which $n$ is the required sample, $X^{2}$ is table value of chi-square for $1 d f$ at the desired confidence level, $N$ represents the population size, $P$ indicates the population proportion $(50 \%)$ and $d$ is the level of accuracy of the estimate expressed as a proportion. Assuming 95\% of confidence level, the sample size for this study was calculated as $n=[(3.841)(25525)(0.5)(1-0.5)] /\left[\left(0.05^{2}\right)(25525-1)\right.$ $+(3.841)(0.5)(1-0.5)]$. After the consideration of $10 \%$ dropout cases, the total sample size needed for this study was 396 students. Students were selected through a convenience sampling method from all faculties (eight) in the Bangi campus. Data collection was carried out between June to December 2018.

\section{Questionnaires and data collection}

The self-administrated questionnaire comprised of 4 sections, including sociodemographic, breakfast consumption patterns, KAP, and barriers related to breakfast consumption. The KAP questionnaire was pre-tested among 30 students and validated using the Cronbach alpha test before the start of the study to evaluate the effectiveness and suitability of the questionnaire. The classification of Cronbach alpha is low $(<0.60)$, acceptable (between $0.60-0.80$ ), and good $(>0.80)$ (George \& Mallery, 2003). The pre-test result showed that the Cronbach alphas for KAP were in the acceptable range of $0.722,0.705$, and 0.784 , respectively. There were $13(\mathrm{~K}), 10(\mathrm{~A})$, and 11 (P) questions respectively. For (K) section, 2, 1, and 0 marks were given if correct, not sure and wrong answers, respectively whilst questions for (A) and $(\mathrm{P})$ sections were given 4 marks for the most ideal attitude and practice and 0 marks for unideal attitude and practice behaviors. The total scores in each category were scored and categorized based on Perumal et al. $(2013)(<40 \%=$ low, $40-80 \%=$ moderate $\&>80 \%=$ high). Breakfast barriers were assessed based on how strongly disagree or agree using a Likert scale of 1 to 4 (strongly disagree $=1$, strongly agree $=4$ ). The Cronbach's alpha for the scale was 0.771 ). Questionnaires were adapted from Hearst et al. (2016). 
Height and weight were measured to the nearest $0.1 \mathrm{~cm}$ and $0.1 \mathrm{~kg}$ using a measuring tape body meter (SECA, Hamburg, Germany) and portable mechanical lithium scale HD-312 (Tanita Corp., Tokyo, Japan). BMI was calculated based on the World Health Organisation (WHO) classification (WHO 1995).

\section{Data analysis}

Data were analyzed using Statistical Package for the Social Sciences (SPSS) version 21.0 (SPSS Incorporation, Chicago, IL, USA) and expressed as mean \pm standard deviation (SD), frequency, and percentage. Before the analysis, the distribution of the data was checked using the Kolmogorov-Smirnov test. Only parametric tests were used in the analysis as all data were normally distributed. Chi-square test was used to compare the frequency of breakfast consumption and analysis of KAP questionnaires whilst one-way analysis of variance was used to compare the means of KAP and barriers scores of breakfast consumption. Pearson correlation was used to determine the relationship between KAP variables. The significant level was considered at $p<0.05$ and $p<0.001$.

\section{RESULTS AND DISCUSSION}

Sociodemographic characteristics of the subjects

In general, a total of 198 male and female subjects (66 males and females in each race) were involved in this study. They were aged between 21 to 23 years old. The mean age of subjects was $21.1 \pm 1.6$ years and no significant difference $(p>0.05)$ was found between the races. The students of this study had normal BMI, $20.0 \pm 4.5 \mathrm{~kg} / \mathrm{m}^{2}$. However, Chinese students $\left(21.4 \pm 3.4 \mathrm{~kg} / \mathrm{m}^{2}\right)$ had significantly lower $(p=0.01)$ BMI than Indian $\left(22.1 \pm 3.9 \mathrm{~kg} / \mathrm{m}^{2}\right)$ and Malay students $\left(23.0 \pm 5.7 \mathrm{~kg} / \mathrm{m}^{2}\right)$. A similar trend whereby the BMI of Chinese students was the lowest compared to their counterparts was also reported elsewhere (Yap et al., 2019; Yahya et al., 2021). Most of the subjects were in the first year of their studies $(40.2 \%)$ and a majority of them were single (99.5\%). On average, most of the students $(50 \%)$ spent only RM5 to RM10 (RM 1 = USD 0.24 [24 May 2021]) daily on foods as just over half of the students (58.8\%) had a monthly allowance of below RM500, which usually financed from scholarship/bursary/ loan or parents/guardians.

Table 1. Sociodemographic characteristics of the subjects

\begin{tabular}{|c|c|c|c|c|}
\hline Characteristics & Overall $(n=396)$ & Malay $(n=132)$ & Chinese $(n=132)$ & Indian $(n=132)$ \\
\hline \multicolumn{5}{|l|}{ Gender } \\
\hline Males & $198(50)$ & $66(50)$ & $66(50)$ & $66(50)$ \\
\hline Females & $198(50)$ & $66(50)$ & $66(50)$ & $66(50)$ \\
\hline \multicolumn{5}{|l|}{ Age groups } \\
\hline $18-20$ years & 166 (41.9) & $68(51.5)$ & $54(40.9)$ & $44(33.3)$ \\
\hline $21-23$ years & $193(48.7)$ & $44(33.3)$ & $69(52.3)$ & $80(30.6)$ \\
\hline $24-26$ years & $37(9.3)$ & $20(15.2)$ & $9(6.8)$ & $8(6.1)$ \\
\hline Average age (years) & $21.1 \pm 1.6$ & $21.1 \pm 1.9$ & $21.0 \pm 1.5$ & $21.0 \pm 1.5$ \\
\hline \multicolumn{5}{|l|}{ Body mass index classification } \\
\hline Underweight $\left(<18.5 \mathrm{~kg} / \mathrm{m}^{2}\right)$ & $24(17.9)$ & $23(17.4)$ & $27(20.5)$ & $21(15.9)$ \\
\hline Normal $\left(18.5-24.9 \mathrm{~kg} / \mathrm{m}^{2}\right)$ & $80(60.4)$ & $72(54.5)$ & $86(65.2)$ & $81(61.4)$ \\
\hline Overweight $\left(25.0-29.9 \mathrm{~kg} / \mathrm{m}^{2}\right)$ & $21(15.7)$ & $23(17.4)$ & $16(12.1)$ & $23(17.4)$ \\
\hline Obese $\left(>30.0 \mathrm{~kg} / \mathrm{m}^{2}\right)$ & $8(6.1)$ & $14(10.6)$ & $3(2.3)$ & $7(5.3)$ \\
\hline Average body mass index $\left(\mathrm{kg} / \mathrm{m}^{2}\right)$ & $20.0 \pm 4.5$ & $23.0 \pm 5.7$ & $21.4 \pm 3.4$ & $22.1 \pm 3.9$ \\
\hline \multicolumn{5}{|l|}{ The academic year of study } \\
\hline Year 1 & $159(40.2)$ & $66(50.0)$ & $60(45.5)$ & $33(25.0)$ \\
\hline Year 2 & $129(32.6)$ & $40(30.3)$ & $54(40.9)$ & $35(26.5)$ \\
\hline Year 3 & $96(24.2)$ & $23(17.4)$ & $18(13.6)$ & $55(41.7)$ \\
\hline Year 4 & $12(3.0)$ & $3(2.3)$ & - & $9(6.8)$ \\
\hline \multicolumn{5}{|l|}{ Marital status } \\
\hline Single & 394 (99.5) & 130 & 132 & 132 \\
\hline Married & $2(0.5)$ & 2 & - & - \\
\hline \multicolumn{5}{|c|}{ The daily budget on foods (Ringgit Malaysia) } \\
\hline RM5 - RM10 & $198(50.0)$ & 92 (69.7) & $48(36.4)$ & $58(43.9)$ \\
\hline RM10 - RM15 & $166(41.9)$ & $36(27.3)$ & $68(51.5)$ & $62(47.0)$ \\
\hline More than RM15 & $32(8.1)$ & $4(3.0)$ & $16(12.1)$ & $12(9.1)$ \\
\hline \multicolumn{5}{|l|}{ Monthly allowance (Ringgit Malaysia) } \\
\hline$<$ RM500 & $233(58.8)$ & $92(69.7)$ & $76(57.6)$ & $65(49.2)$ \\
\hline RM500 - RM1000 & $122(30.8)$ & $29(22.0)$ & $43(32.6)$ & $50(37.9)$ \\
\hline$>\mathrm{RM} 1000$ & $41(10.4)$ & $11(8.3)$ & $13(9.8)$ & $17(12.9)$ \\
\hline
\end{tabular}

Data are expressed as number (percentage), $n(\%)$, and mean \pm standard deviation. 


\section{Breakfast consumption habits of the subjects}

The breakfast consumption habits are presented in Table 2. Overall, more than half of the sample population $(68.2 \%)$ took breakfast in a week. Previous studies reported that the frequencies of breakfast consumption among Malaysian university students were $59.7 \%$ in Kutty et al. (2015), 62\% in Chawla et al. (2019), 70.8\% in Moy et al. (2009), and 73.6\% in Isa and Masuri (2011). Our data seems to fit the trend too. Globally, a wide range of breakfast consumption patterns was reported among university students, ranging from $48.1 \%$ to $87.6 \%$ (Javaid, 2020). When compared between the races, the consumption was higher among Chinese (75.8\%) compared to Malay $(63.6 \%)$ and Indian students $(65.2 \%)$ but no significant difference $(p>0.05)$ was demonstrated. Additionally, Chinese students also had significantly higher $(p<0.05)$ breakfast frequencies (between 6-7 times per week) (50\%) compared to their counterparts. By our findings, Moy et al. (2009) also reported that Chinese undergraduate students had the highest breakfast consumption (81.7\%) compared to other groups $($ Malay $=65.7 \%$, Indian $=70 \%$ ). The fact that Malay and Indian had lower breakfast consumption than Chinese is a matter of concern as they were the main groups that related with higher cases of obesity and diabetes type 2 in Malaysia (National Health \& Morbidity Survey, 2019), health conditions that have been reported with breakfast skipping in many studies (Ballon et al., 2019; Ma et al., 2020). Therefore, it is important to understand the underlying factors for both groups to skip breakfast consumption.

When categorized into the timeframe, subjects generally had their breakfast between 8.00 to 10.00 am $(64.4 \%)$ whilst the very least of them $(10.4 \%)$ had breakfast before $8.00 \mathrm{am}$. Contradictory, $58.5 \%$ of undergraduate students in a study reported by Cebirbay et al. (2011) took breakfast between 6.00 to $8.00 \mathrm{am}$. Our study also found that $25.3 \%$ of the subjects took their breakfast after $10.00 \mathrm{am}$. It might be possible that this group of students took their breakfast only after they had their early morning class. Delaying breakfast time could result in delaying lunch and dinner times, an eating pattern known as "eating jet lag". This eating behavior has been demonstrated to have an association with weight gain, in which the longer eating jet lag, the higher chances a person to gain weight (ZeronRugerio et al., 2019). People need to be educated to eat at a similar time daily as misalignment of mealtime could affect our peripheral clocks, one of the main components that regulate our circadian rhythms (Moreno et al., 2019), this leads to disruption of metabolic process in our body, one of which is body weight regulation.

Table 2. Breakfast consumption patterns of the subjects

\begin{tabular}{|c|c|c|c|c|c|}
\hline \multirow{2}{*}{ Variables } & \multicolumn{4}{|c|}{ Total, $n(\%)$} & \multirow{2}{*}{$p$-value } \\
\hline & Overall $(n=396)$ & Malay $(n=132)$ & Chinese $(n=132)$ & Indian $(n=132)$ & \\
\hline \multicolumn{6}{|l|}{ Are you a breakfast consumer? } \\
\hline Yes & $270(68.2)$ & $84(63.6)$ & $100(75.8)$ & $86(65.2)$ & - \\
\hline No & $126(31.8)$ & $48(36.4)$ & $32(24.2)$ & $46(34.8)$ & - \\
\hline \multicolumn{6}{|c|}{ Frequency of breakfast consumption in a week } \\
\hline $0-1$ time & $27(6.8)$ & $8(6.1)$ & $6(4.5)$ & $13(9.8)$ & 0.212 \\
\hline $2-3$ times & $116(29.3)$ & $48(36.4)$ & $30(22.7)$ & $38(28.8)$ & 0.050 \\
\hline $4-5$ times & $111(28.0)$ & $38(28.8)$ & $30(22.7)$ & $43(32.6)$ & 0.199 \\
\hline $6-7$ times & $142(35.9)$ & $38(28.8)^{\mathrm{b}}$ & $66(50.0)^{\mathrm{a}}$ & $38(28.8)^{b}$ & $<0.001^{* *}$ \\
\hline \multicolumn{6}{|l|}{ Time taking breakfast } \\
\hline Before $8.00 \mathrm{am}$ & $41(10.4)$ & $9(6.8)$ & $22(16.7)$ & $10(7.6)$ & - \\
\hline 8.00 to $10.00 \mathrm{am}$ & $255(64.4)$ & $91(68.9)$ & $88(66.7)$ & $76(57.6)$ & - \\
\hline After $10.00 \mathrm{am}$ & $100(25.3)$ & $32(24.2)$ & $22(16.7)$ & $46(34.8)$ & - \\
\hline \multicolumn{6}{|c|}{ Amount spent on breakfast (Ringgit Malaysia) } \\
\hline Less than RM2 & $131(33.1)$ & $45(34.1)$ & $38(28.8)$ & $48(36.4)$ & - \\
\hline RM2 - RM5 & $220(55.6)$ & $74(56.1)$ & $80(60.6)$ & $55(50.0)$ & - \\
\hline RM5 - RM8 & $36(9.1)$ & $10(7.6)$ & $11(8.3)$ & $15(11.4)$ & - \\
\hline RM8 and more & $9(2.3)$ & $3(2.3)$ & $3(2.3)$ & $3(2.3)$ & - \\
\hline \multicolumn{6}{|l|}{ The place to take breakfast } \\
\hline Cafeteria in college / faculty & $260(65.7)$ & $88(33.8)$ & $76(29.2)$ & $96(36.9)$ & - \\
\hline Restaurant / food stall & $80(20.2)$ & $27(33.8)$ & $31(38.8)$ & $22(27.5)$ & - \\
\hline Fast food restaurant & $13(3.3)$ & $3(23.1)$ & $4(30.8)$ & $6(46.2)$ & - \\
\hline Home / Hostel & $205(51.8)$ & $72(35.1)$ & $90(43.9)$ & $43(21.0)$ & - \\
\hline \multicolumn{6}{|l|}{ With whom having breakfast } \\
\hline With friends & $149(37.6)$ & $64(48.5)$ & $33(25.0)$ & $52(39.4)$ & - \\
\hline Alone & $247(62.4)$ & $68(51.5)$ & 99 (75.0) & $80(60.6)$ & - \\
\hline
\end{tabular}

a,bSignificant difference between ethnic groups at ${ }^{* \star} p<0.001$, tested using Chi-square test. 
Table 3. Knowledge, attitude, and practice scores of the breakfast consumption

\begin{tabular}{|c|c|c|c|c|c|}
\hline \multirow{2}{*}{ Variables } & \multicolumn{4}{|c|}{ Means \pm standard deviation (\%) } & \multirow{2}{*}{$p$-value } \\
\hline & Overall $(n=396)$ & Malay $(n=132)$ & Chinese $(n=132)$ & Indian $(n=132)$ & \\
\hline Knowledge & $64.2 \pm 21.1$ & $63.5 \pm 22.0$ & $67.6 \pm 18.8$ & $61.7 \pm 21.1$ & 0.06 \\
\hline Attitude & $68.8 \pm 10.5$ & $67.2 \pm 11.4$ & $69.9 \pm 9.6$ & $69.4 \pm 10.4$ & 0.08 \\
\hline Practice & $51.1 \pm 23.1$ & $44.7 \pm 23.0^{a}$ & $57.2 \pm 23.1^{b}$ & $51.4 \pm 21.9^{a b}$ & $<0.001^{* *}$ \\
\hline
\end{tabular}

a,bDifferent alphabet in the same column shows a significant difference between ethnic groups at ${ }^{* *} p<0.001$, tested using analysis of variance.

Most of the subjects (55.6\%) spent between RM2 to RM5 for breakfast, which suggested that breakfast was generally purchased and seldomly self-catered at their residence (51.8\%). In general, the amount spent on breakfast can be considered affordable for students compared to the breakfast price outside of the university. Indeed, more than half of the subjects $(65.7 \%)$ reported that they usually had their breakfast at college or faculty cafeterias than other eateries. Subjects of this study also reported that they usually had their breakfast on their own $(62.4 \%)$ than with friends $(37.6 \%)$. This is because students need to rush in the morning and have different classes to attend, therefore having breakfast on their own seems to be more convenient. However, Chin and Mohd Nasir (2009) suggested that individuals who eat alone tend to skip meals. In contrast, students in this study would not mind eating breakfast alone as $66.5 \%$ disagreed with the statement "I think that I would not eating breakfast if I am alone" (KAP attitude question). No significant difference $(p>0.05)$ between races was seen.

\section{Knowledge, attitude, and practice scores and correlations}

Overall, KAP scores were at moderate levels (Table 3). However, the practice score $(51.1 \pm 23.1)$ was the lowest compared to attitude $(68.8 \pm 10.5)$ and knowledge $(64.2 \pm 21.1)$ scores. This means that students had good knowledge and positive attitudes towards optimal breakfast consumption, but still unable and not as good as their attitudes to consuming breakfast accordingly. Comparison between groups demonstrated that Chinese students had the highest KAP scores compared to other races. However, only practice scores $(57.2 \pm 23.1)$ were significant $(p<0.001)$ when compared with Malay $(44.7 \pm 23.0)$, but not with Indian $(51.4 \pm 21.9)$. This finding has mirrored the analysis of breakfast habits among the groups in which the Chinese had the highest breakfast consumption followed by Indian and Malay.

There was a positive significant correlation $(p<0.001)$ between KAP variables. Similar findings were also shown by Sukkrachang (2017) in which a significant positive correlation was demonstrated between KAP variables of breakfast consumption behaviors among primary school children in Songkhla, Thailand. Alves and Precioso (2020) also found a significant correlation between the variables in their study on healthy diet among university students in Portugal. In our study, the correlation between attitude and practice was found to be the highest $(r=0.443 ; p<0.01)$ compared to knowledge and attitude $(r=0.421 ; p<0.01)$ and knowledge and practice $(r=0.166 ; p=0.001)$. This means that knowledge, positive attitudes, and belief on the benefits of breakfast on health would increase the frequency of breakfast consumption. Contradictory, people with negative attitudes would not necessarily increase their breakfast consumption although they have good knowledge of it (Sukkachang, 2017).

\section{Analysis of knowledge, attitude and practice questionnaires}

Analysis of knowledge questionnaires (Table 4) showed that there were significant differences for statements; "breakfast provides numerous vitamins and minerals for our body" ( $p=0.006)$, "high-fiber breakfasts help me to feel full for longer" $(p=0.006)$, and "eating breakfast will lead to a consumption of unhealthy snacks" ( $p=0.002)$. Generally, between $52.5 \%$ to $81.6 \%$ of students able to answer correctly all questions, which means students did have a basic and good knowledge about the importance of breakfast on health.

In the attitude questionnaire analysis section, questions of "I think it is difficult to get well-balanced nutritious food for breakfast in the university" and "I think university cafeteria sell similar and typical food for breakfast" were significantly different ( $p=0.020$ and $p=0.022$, respectively). This would mean that students are looking for a variety of foods as usually university cafeteria only provides typical Malaysian breakfast such as nasi lemak, nasi goreng, roti canai, and others. As we know, these types of foods commonly lack vegetables, contain high carbohydrates and low dietary fiber (Tarmizi et al., 2020). Therefore, caterers of university cafeterias need to be educated on the importance of providing healthy foods among the students and subsequently trained them to create healthy food choice sections in their cafeterias. Foods such as soups, cereals, sandwiches, vegetables, and fruits can be added to 
this section to increase variability and availability of healthy food choices not just for students, but also for staff working on campus.

In the analysis, the question of "I skip breakfast to save money" $(p<0.001)$ was also found to be highly rated by Malay students compared to Chinese and Indian students. A similar trend was also seen for the statement "I skip breakfast because I am lacking money" $(p<0.001)$ in practice and "high cost of breakfast" $(p=0.03)$ in the barrier analysis section. These analyses could be related to the financial status of the subjects. In this study, $69.7 \%$ of Malay students reported that their monthly allowance was less than RM500 per month compared to $57.6 \%$ Chinese and $49.2 \%$ Indian. In Malaysia, university students generally received scholarships or study loans throughout their study period. However, they are students who have not received any kind of sponsorship and depend on parents' supports, or received a scholarship but still need parents' support (Wan Azdie et al., 2019). Regrettably, as the information of the source of allowance was not investigated in this study, therefore the linkage between the allowance and its financial source cannot be verified. It is presumed that the students have saved up money for study purposes and other living expenses. These students could experience food insecurity if they had financial affordability problems during their studies. Wan Azdie et al. (2019) reported that $54.4 \%$ of university students had food insecurity problems and the problem was related to factors including time constraints, use of money on books, miscellaneous items, parents' income, and scholarship type. Therefore, it is suggested that the relevant authorities including the student association could address this issue, perhaps one of the many ways, implementing a free food bank for the needed students.

In the analysis of practice questionnaires, significant differences were demonstrated for the questions of "I always take cereals for breakfast compared to local foods" (e.g. Nasi lemak) $(p=0.045)$, "I substitute breakfast with snacking" $(p<0.001)$, "I will have brunch if I did not have breakfast before $10.00 \mathrm{am}$ " $(p<0.001)$, "I only eat breakfast if I am at my parents' home compared to in the campus" $(p=0.002)$, "I only take breakfast if I am hungry" $(p<0.001)$, "I skip breakfast if my class starts at 8.00 am" $(p=0.001)$ and "I skip breakfast because I am lack of money" $(p<0.001)$. From the analysis, about $50 \%$ of Malay and Indian students rated agreed to take cereals for breakfast than common Malaysian breakfast. Therefore, it is strongly suggested that university food caterers could also sell these foods in their cafeterias to give more breakfast choices to students. The most apparent analysis was $80.3 \%$ of Malay agreed that they would go for brunch if they do not have breakfast before 10.00 am compared to their peers (Chinese: $53.8 \%$, Indian: $65.9 \%$ ). Similarly, they also rated high scores for taking breakfast only if they are hungry (Malay: $61.4 \%$, Chinese: $31.8 \%$, and Indian: $55.3 \%$ ). In contrast, Indian students tended to skip breakfast (63.6\%) for $8.00 \mathrm{am}$ class (Malay: $56.1 \%$, Chinese: $45.4 \%$ ). These results demonstrated that these students need to be educated about healthy eating behavior particularly among first-year students who are still in the adapting process with university life. In this study, $40 \%$ of them were first-year students. Introducing Malaysian Dietary guidelines to students, adding an elective course in the university curriculum and effective awareness campaigns on healthy eating behavior and healthier food choice are some of the mechanisms that could be implemented to promote changes among them.

Table 5 shows the scores of barriers to breakfast consumption among subjects. The mean total score of $25.55 \pm 4.35$ indicated that students acknowledged the barriers as moderate (total marks: 40). No significant difference $(p>0.05)$ between the groups was found. Analysis of the barrier to breakfast consumption showed that "class started very early in the morning", "limited choice of breakfast" and "not enough time were the most popular reasons that caused students to skip their breakfast. Awang Damit et al. (2019) also postulated that early morning class could be the reason that subjects in their study had no time for breakfast. The authors also suggested that classes during this hour should have a short break to allow students to have their breakfast. In UKM, most of the classes start at 9.00 am. However, students possibly prioritized their time to get ready to dress and get a transport to go to the class rather than eating breakfast particularly when they are rushing. Lack of time was consistently reported as a barrier to breakfast consumption in numerous studies among university students and young adults (Pendergast et al., 2016; Javaid, 2020). Additionally, Malay students had significantly higher $(p=0.03)$ scores $(2.52 \pm 0.94)$ compared with Chinese $(2.27 \pm 0.83)$ and Indian students $(2.27 \pm$ 0.92 ) on the reason of "high cost of breakfast". In addition, the "breakfast will cause obesity" statement had the lowest overall score $(1.62 \pm 0.68)$. This means that students did aware that consumption of breakfast would not lead to obesity. Other studies also showed that obesity is not a reason university students skipped breakfast (Pendergast et al., 2016; Javaid, 2020). The statements of "lack of food availability in UKM" and "lack of food choices in UKM" were also agreed by many students. Indeed, environmental factors such as food availability, food types, and breakfast places were reported to affect breakfast consumption among university students $(p<0.01)$ (Mat Ludin et al., 2016). 
Table 4. Analysis of knowledge, attitude, and practice questionnaires of breakfast consumption among subjects

\begin{tabular}{|c|c|c|c|c|c|}
\hline \multirow{2}{*}{ Variables } & \multicolumn{4}{|c|}{ Total, $n(\%)$} & \multirow{2}{*}{$p$-value } \\
\hline & Overall $(n=396)$ & Malay $(n=132)$ & Chinese $(n=132)$ & Indian $(n=132)$ & \\
\hline \multicolumn{6}{|l|}{ Knowledge } \\
\hline \multicolumn{6}{|c|}{ Breakfast consumption will increase calorie intake in the next meal } \\
\hline Not sure & $129(32.6)$ & $49(37.1)$ & $31(23.5)$ & $49(31.7)$ & 0.058 \\
\hline False & $221(55.8)$ & $65(49.2)$ & $86(65.1)$ & $70(53.0)$ & \\
\hline True & $46(11.6)$ & $18(13.6)$ & $15(11.4)$ & $13(9.8)$ & \\
\hline \multicolumn{6}{|c|}{ Breakfast provides numerous vitamins and minerals for our body } \\
\hline Not sure & $77(19.4)$ & $37(28.0)$ & $14(10.6)$ & $26(19.7)$ & $0.006^{*}$ \\
\hline False & $24(6.1)$ & $9(6.8)$ & $6(4.5)$ & $9(6.8)$ & \\
\hline True & $295(74.5)$ & $86(65.1)$ & $112(84.5)$ & $97(73.5)$ & \\
\hline \multicolumn{6}{|c|}{ High-fiber breakfasts help me to feel full for longer } \\
\hline Not sure & $79(19.2)$ & $26(19.7)$ & $19(14.4)$ & $34(25.8)$ & $0.006^{*}$ \\
\hline False & $61(15.4)$ & $30(22.7)$ & $19(14.4)$ & $12(9.1)$ & \\
\hline True & $256(64.6)$ & $76(57.6)$ & $94(71.2)$ & $86(65.1)$ & \\
\hline \multicolumn{6}{|c|}{ Eating breakfast helps students to concentrate and retain new information in class } \\
\hline Not sure & $46(11.6)$ & $17(12.9)$ & $16(12.1)$ & $13(9.8)$ & 0.116 \\
\hline False & $32(8.7)$ & $14(10.6)$ & $4(3.3)$ & $14(10.6)$ & \\
\hline True & $318(80.3)$ & $101(76.5)$ & $112(84.8)$ & $105(79.5)$ & \\
\hline \multicolumn{6}{|c|}{ Eating breakfast will lead to a consumption of unhealthy snacks } \\
\hline Not sure & $66(16.7)$ & $31(2.6)$ & $11(8.3)$ & $24(18.2)$ & $0.002^{*}$ \\
\hline False & $281(71.0)$ & $88(66.7)$ & $108(81.8)$ & $85(64.4)$ & \\
\hline True & $49(12.4)$ & $13(9.8)$ & $13(9.8)$ & $23(17.4)$ & \\
\hline \multicolumn{6}{|c|}{ Breakfast that high in fiber and protein, but low in fats and sugars can reduce concentration levels during the learning process } \\
\hline Not sure & $59(16.0)$ & $24(18.2)$ & $22(16.7)$ & $13(9.8)$ & 0.201 \\
\hline False & $233(58.8)$ & $79(59.8)$ & $71(53.8)$ & $83(62.9)$ & \\
\hline True & $104(26.3)$ & $29(22.0)$ & $39(29.5)$ & $36(27.3)$ & \\
\hline \multicolumn{6}{|c|}{ Regular consumption of a healthy breakfast will help to reduce body weight } \\
\hline Not sure & $146(36.9)$ & $39(29.5)$ & $52(39.4)$ & $55(41.7)$ & 0.092 \\
\hline False & $42(10.6)$ & $11(8.3)$ & $14(10.6)$ & $17(12.9)$ & \\
\hline True & $208(52.5)$ & $82(62.1)$ & $66(50.0)$ & $60(45.5)$ & \\
\hline \multicolumn{6}{|c|}{ Risks of heart diseases can be reduced by eating high energy and fibrous breakfast } \\
\hline Not sure & $96(24.2)$ & $32(24.2)$ & $32(24.2)$ & $32(24.2)$ & 0.911 \\
\hline False & $29(7.3)$ & $12(9.1)$ & $8(6.1)$ & $9(6.8)$ & \\
\hline True & $271(68.4)$ & $88(66.7)$ & $92(69.7)$ & $91(68.9)$ & \\
\hline \multicolumn{6}{|c|}{ The best time to have breakfast is between 6.00 to 10.00 in the morning } \\
\hline Not sure & $65(16.4)$ & $20(15.2)$ & $23(17.4)$ & $22(16.7)$ & 0.077 \\
\hline False & $28(7.1)$ & $5(3.8)$ & $7(5.3)$ & $16(12.1)$ & \\
\hline True & $303(76.5)$ & $102(77.3)$ & $102(77.3)$ & $94(71.2)$ & \\
\hline \multicolumn{6}{|c|}{ Breakfast will increase the consumption of food high in fat such as fried foods } \\
\hline Not sure & $75(18.9)$ & $30(22.7)$ & $22(16.7)$ & $23(17.4)$ & 0.345 \\
\hline False & $256(64.6)$ & $80(60.6)$ & $93(70.5)$ & $83(62.9)$ & \\
\hline True & $65(16.4)$ & $22(16.7)$ & $17(12.9)$ & $26(19.7)$ & \\
\hline \multicolumn{6}{|c|}{ Breakfast provides glucose as a fuel to our brain to function properly after a long overnight fasting } \\
\hline Not sure & $109(27.5)$ & $43(32.6)$ & $29(22.0)$ & $37(28.0)$ & 0.403 \\
\hline False & $33(8.3)$ & $9(6.8)$ & $12(9.1)$ & $12(9.1)$ & \\
\hline True & $254(64.1)$ & $80(60.6)$ & $91(68.9)$ & $83(62.9)$ & \\
\hline Eating breakfast help & to have a good $\mathrm{m}$ & mprove students & ic performance & & \\
\hline Not sure & $49(12.4)$ & $15(11.4)$ & $16(12.1)$ & $18(13.6)$ & 0.903 \\
\hline False & $24(6.1)$ & $9(6.8)$ & $9(6.8)$ & $6(4.5)$ & \\
\hline True & $323(81.6)$ & $108(81.8)$ & $107(81.1)$ & $108(81.8)$ & \\
\hline Breakfast that high in & ber will helps indic & & & & \\
\hline Not sure & $90(22.7)$ & $31(23.5)$ & $25(18.9)$ & $34(25.8)$ & 0.555 \\
\hline False & $21(5.3)$ & $6(4.5)$ & $6(4.5)$ & $6(4.5)$ & \\
\hline True & $285(72.0)$ & $95(72.0)$ & $101(76.5)$ & $89(67.4)$ & \\
\hline Attitudes & & & & & \\
\hline I believe breakfast in & ke helps to mainta & thy body & & & \\
\hline Strongly disagree & $16(4.0)$ & $7(5.3)$ & $3(2.3)$ & $6(4.5)$ & 0.679 \\
\hline Disagree & $7(1.8)$ & $2(1.5)$ & $2(1.5)$ & $3(2.3)$ & \\
\hline Not sure & $24(6.1)$ & $7(5.3)$ & $6(4.5)$ & $11(8.3)$ & \\
\hline Agree & $191(48.2)$ & $68(51.5)$ & $67(50.8)$ & $56(42.4)$ & \\
\hline Strongly agree & $158(39.9)$ & $48(36.4)$ & $54(40.9)$ & $56(42.4)$ & \\
\hline
\end{tabular}


Table 1 continued...

\begin{tabular}{|c|c|c|c|c|c|}
\hline \multicolumn{6}{|c|}{ I believe breakfast intake will increase the absorption of vitamins and minerals } \\
\hline Strongly disagree & $5(1.3)$ & $3(2.3)$ & $1(0.8)$ & $1(0.8)$ & \multirow[t]{5}{*}{0.801} \\
\hline Disagree & $9(2.3)$ & $3(2.3)$ & $3(2.3)$ & $3(2.3)$ & \\
\hline Not sure & $64(16.2)$ & $22(16.7)$ & $18(13.6)$ & $24(18.2)$ & \\
\hline Agree & $185(46.7)$ & $62(47.0)$ & $68(51.5)$ & $55(41.7)$ & \\
\hline Strongly agree & $133(33.6)$ & $42(31.8)$ & $42(31.8)$ & $49(37.1)$ & \\
\hline \multicolumn{6}{|c|}{ I think breakfast intake will help me to meet my daily total dietary fiber intake } \\
\hline Strongly disagree & $6(1.5)$ & $4(3.0)$ & $1(0.8)$ & $1(0.8)$ & \multirow[t]{5}{*}{0.672} \\
\hline Disagree & $22(5.6)$ & $8(6.1)$ & $7(5.3)$ & $7(5.3)$ & \\
\hline Not sure & $117(29.5)$ & $40(30.3)$ & $41(31.1)$ & $36(27.3)$ & \\
\hline Agree & $151(38.1)$ & $46(34.8)$ & $55(41.7)$ & $50(37.9)$ & \\
\hline Strongly agree & $100(25.3)$ & $34(25.8)$ & $28(21.2)$ & $38(28.8)$ & \\
\hline \multicolumn{6}{|c|}{ I believe that breakfast intake helps to reduce the risk of heart disease, diabetes, and high blood pressure } \\
\hline Strongly disagree & $9(2.3)$ & $3(2.3)$ & $1(0.8)$ & $5(3.8)$ & \multirow[t]{5}{*}{0.645} \\
\hline Disagree & $25(6.3)$ & $10(7.6)$ & $9(6.8)$ & $6(4.5)$ & \\
\hline Not sure & $106(26.8)$ & $30(22.7)$ & $41(31.1)$ & $35(26.5)$ & \\
\hline Agree & $156(39.4)$ & $53(40.1)$ & $51(38.6)$ & $52(39.4)$ & \\
\hline Strongly agree & $100(25.3)$ & $36(27.3)$ & $30(22.7)$ & $34(25.8)$ & \\
\hline \multicolumn{6}{|c|}{ I believe that I will be more focused during studying if I consume breakfast } \\
\hline Strongly disagree & $2(0.5)$ & $1(0.8)$ & $0(0.0)$ & $1(0.8)$ & \multirow[t]{5}{*}{0.67} \\
\hline Disagree & $16(4.0)$ & $7(5.3)$ & $6(4.5)$ & $3(2.3)$ & \\
\hline Not sure & $50(12.6)$ & $19(14.4)$ & $18(13.6)$ & $13(9.8)$ & \\
\hline Agree & $180(45.5)$ & $60(45.5)$ & $62(47.0)$ & $58(43.9)$ & \\
\hline Strongly agree & $148(37.4)$ & $45(34.1)$ & $46(34.8)$ & $57(43.2)$ & \\
\hline \multicolumn{6}{|c|}{ I prioritize my morning classes over-consuming breakfast } \\
\hline Strongly disagree & $36(9.1)$ & $12(9.1)$ & $11(8.3)$ & $13(9.8)$ & \multirow[t]{5}{*}{0.819} \\
\hline Disagree & $115(29.0)$ & $35(26.5)$ & $43(32.6)$ & $37(28.0)$ & \\
\hline Not sure & $65(16.4)$ & $22(16.7)$ & $22(16.7)$ & $21(15.9)$ & \\
\hline Agree & $121(30.6)$ & $38(28.8)$ & $42(31.8)$ & $41(31.1)$ & \\
\hline Strongly agree & $59(14.9)$ & $25(18.9)$ & $14(10.6)$ & $20(15.2)$ & \\
\hline \multicolumn{6}{|c|}{ I think it is difficult to get well-balanced nutritious food for breakfast in the university } \\
\hline Strongly disagree & $43(10.9)$ & $23(17.4)$ & $4(3.0)$ & $16(12.1)$ & \multirow[t]{5}{*}{$0.020^{*}$} \\
\hline Disagree & $122(30.8)$ & $41(31.1)$ & $40(30.3)$ & $41(31.1)$ & \\
\hline Not sure & $79(19.2)$ & $23(17.4)$ & $33(25)$ & $23(17.4)$ & \\
\hline Agree & $107(27.0)$ & $30(22.7)$ & $37(28.0)$ & $40(30.3)$ & \\
\hline Strongly agree & $45(11.4)$ & $15(11.4)$ & $18(13.6)$ & $12(9.1)$ & \\
\hline \multicolumn{6}{|c|}{ I think that I would not eating breakfast if I am alone } \\
\hline Strongly disagree & $118(29.8)$ & $35(26.5)$ & $49(37.1)$ & $34(25.8)$ & 0.152 \\
\hline Disagree & $146(36.9)$ & $52(39.4)$ & $47(35.6)$ & $47(35.6)$ & \\
\hline Not sure & $55(13.9)$ & $14(10.6)$ & $17(12.9)$ & $24(18.2)$ & \\
\hline Agree & $58(14.6)$ & $22(16.7)$ & $17(12.9)$ & $19(14.4)$ & \\
\hline Strongly agree & $19(4.8)$ & $9(6.8)$ & $2(1.5)$ & $8(6.1)$ & \\
\hline I skip breakfast to sa & honey & & & & \\
\hline Strongly disagree & $98(24.7)$ & $22(16.7)$ & $39(29.5)$ & $37(28.0)$ & $<0.001^{* *}$ \\
\hline Disagree & $125(31.6)$ & $24(18.2)$ & $52(39.4)$ & $49(37.1)$ & \\
\hline Not sure & $58(14.6)$ & $25(18.9)$ & $17(12.9)$ & $16(12.1)$ & \\
\hline Agree & $84(21.2)$ & $41(31.1)$ & $19(14.4)$ & $24(18.2)$ & \\
\hline Strongly agree & $31(7.8)$ & $20(15.2)$ & $5(3.8)$ & $6(4.5)$ & \\
\hline I think the university & eria sells $\sin$ & mon Malays & reakfast & & \\
\hline Strongly disagree & $32(8.1)$ & $14(10.6)$ & $10(7.6)$ & $8(6.1)$ & $0.022^{*}$ \\
\hline Disagree & $43(10.9)$ & $12(9.1)$ & $14(10.6)$ & $17(12.9)$ & \\
\hline Not sure & $66(16.7)$ & $17(12.9)$ & $28(21.2)$ & $21(15.9)$ & \\
\hline Agree & $145(36.6)$ & $38(28.8)$ & $54(40.0)$ & $53(40.1)$ & \\
\hline Strongly agree & $110(27.8)$ & $51(38.6)$ & $26(19.7)$ & $33(25.0)$ & \\
\hline I think early morning & ses lead stud & reakfast & & & \\
\hline Strongly disagree & $36(9.1)$ & $14(10.6)$ & $11(16.7)$ & $11(16.7)$ & 0.100 \\
\hline Disagree & $53(13.4)$ & $17(12.9)$ & $15(11.4)$ & $21(15.9)$ & \\
\hline Not sure & $65(16.4)$ & $21(15.9)$ & $25(18.9)$ & $19(14.4)$ & \\
\hline Agree & $133(33.6)$ & $35(26.5)$ & $56(42.4)$ & $42(31.8)$ & \\
\hline Strongly agree & $109(27.5)$ & $45(34.1)$ & $25(18.9)$ & $39(29.5)$ & \\
\hline Practise & & & & & \\
\hline I substitute breakfast & snacking & & & & \\
\hline Strongly disagree & $93(23.5)$ & $19(14.4)$ & $39(29.5)$ & $35(26.5)$ & $<0.001^{* *}$ \\
\hline Disagree & $183(46.2)$ & $53(40.1)$ & $53(40.1)$ & $56(42.4)$ & \\
\hline Agree & $110(27.8)$ & $55(41.7)$ & $37(28.0)$ & $38(28.8)$ & \\
\hline Strongly agree & $10(2.5)$ & $5(3.8)$ & $3(2.3)$ & $3(2.3)$ & \\
\hline
\end{tabular}


Table 1 continued...

\begin{tabular}{|c|c|c|c|c|c|}
\hline \multicolumn{6}{|c|}{ I will have brunch if I did not have breakfast before 10.00 am } \\
\hline Strongly disagree & $40(10.1)$ & $8(6.1)$ & $17(12.9)$ & $15(11.4)$ & \multirow[t]{4}{*}{$<0.001^{* *}$} \\
\hline Disagree & $92(23.2)$ & $18(13.6)$ & $44(33.3)$ & $30(22.7)$ & \\
\hline Agree & $176(44.4)$ & $66(50.0)$ & $54(40.9)$ & $56(42.4)$ & \\
\hline Strongly agree & $88(22.2)$ & $40(30.3)$ & $17(12.9)$ & $31(23.5)$ & \\
\hline \multicolumn{6}{|c|}{ I only take dairy products as breakfast } \\
\hline Strongly disagree & $41(10.4)$ & $12(9.1)$ & $14(10.6)$ & $15(11.4)$ & \multirow[t]{4}{*}{0.913} \\
\hline Disagree & $223(56.3)$ & $74(56.1)$ & $78(59.1)$ & $71(53.8)$ & \\
\hline Agree & $119(30.1)$ & $40(30.3)$ & $37(28.0)$ & $42(31.8)$ & \\
\hline Strongly agree & $13(3.3)$ & $6(4.5)$ & $3(2.3)$ & $4(3.0)$ & \\
\hline \multicolumn{6}{|c|}{ I only take protein-based food for breakfast } \\
\hline Strongly disagree & $42(10.6)$ & $13(9.8)$ & $13(9.8)$ & $16(12.1)$ & \multirow[t]{4}{*}{0.686} \\
\hline Disagree & $246(62.1)$ & $77(58.3)$ & $86(65.1)$ & $83(62.9)$ & \\
\hline Agree & $95(24.0)$ & $35(26.5)$ & $30(22.7)$ & $30(22.7)$ & \\
\hline Strongly agree & $13(3.3)$ & $7(5.3)$ & $3(2.3)$ & $3(2.3)$ & \\
\hline \multicolumn{6}{|c|}{ I always take cereals for breakfast compared to local foods (e.g. Nasi lemak) } \\
\hline Strongly disagree & $22(5.6)$ & $9(6.8)$ & $6(4.5)$ & $7(5.3)$ & \multirow[t]{4}{*}{$0.045^{*}$} \\
\hline Disagree & $146(36.9)$ & $53(40.2)$ & $34(25.8)$ & $59(44.7)$ & \\
\hline Agree & $171(43.2)$ & $52(39.4)$ & $70(53.0)$ & $49(37.1)$ & \\
\hline Strongly agree & $57(14.4)$ & $18(13.6)$ & $22(16.7)$ & $17(12.9)$ & \\
\hline \multicolumn{6}{|c|}{ I only eat breakfast if I am at my parents' home compared to on the campus } \\
\hline Strongly disagree & $61(15.4)$ & $13(9.8)$ & $31(23.5)$ & $17(12.9)$ & \multirow[t]{4}{*}{$0.002^{*}$} \\
\hline Disagree & $144(36.4)$ & $44(33.3)$ & $50(37.9)$ & $50(37.9)$ & \\
\hline Agree & $112(28.3)$ & $43(32.6)$ & $38(28.8)$ & $31(23.5)$ & \\
\hline Strongly agree & $79(19.9)$ & $32(24.2)$ & $13(9.8)$ & $34(25.8)$ & \\
\hline \multicolumn{6}{|c|}{ I only take breakfast if I am hungry } \\
\hline Strongly disagree & $73(18.4)$ & $12(9.1)$ & $35(26.5)$ & $26(19.7)$ & \multirow[t]{4}{*}{$<0.001^{* *}$} \\
\hline Disagree & $127(32.1)$ & $39(29.5)$ & $55(41.7)$ & $33(25.0)$ & \\
\hline Agree & $140(35.4)$ & $57(43.2)$ & $35(26.5)$ & $48(36.4)$ & \\
\hline Strongly agree & $56(14.1)$ & $24(18.2)$ & $7(5.3)$ & $25(18.9)$ & \\
\hline \multicolumn{6}{|c|}{ I skip breakfast if my class starts at $8.00 \mathrm{am}$} \\
\hline Strongly disagree & $54(13.6)$ & $9(6.8)$ & $27(20.5)$ & $18(13.6)$ & \multirow[t]{4}{*}{$0.001^{*}$} \\
\hline Disagree & $124(31.3)$ & $49(37.1)$ & $45(34.1)$ & $30(22.7)$ & \\
\hline Agree & $152(38.4)$ & 47 (35.6) & $49(37.1)$ & $56(42.4)$ & \\
\hline Strongly agree & $66(16.7)$ & $27(20.5)$ & $11(8.3)$ & $28(21.2)$ & \\
\hline \multicolumn{6}{|c|}{ I skip breakfast because I am lacking money } \\
\hline Strongly disagree & $82(20.7)$ & $12(9.1)$ & $33(25.0)$ & $37(28.0)$ & \multirow[t]{4}{*}{$<0.001^{* *}$} \\
\hline Disagree & $181(45.7)$ & $49(37.1)$ & $70(53.3)$ & $62(47.0)$ & \\
\hline Agree & $100(25.3)$ & $50(37.9)$ & $23(17.4)$ & $27(20.5)$ & \\
\hline Strongly agree & $33(8.3)$ & $21(15.9)$ & $6(4.5)$ & $6(4.5)$ & \\
\hline \multicolumn{6}{|c|}{ I do not have enough time to buy breakfast } \\
\hline Strongly disagree & $54(13.6)$ & $12(9.1)$ & $23(17.4)$ & $19(14.4)$ & \multirow[t]{4}{*}{0.126} \\
\hline Disagree & $128(32.3)$ & $42(31.8)$ & $42(31.8)$ & $44(33.3)$ & \\
\hline Agree & $150(37.9)$ & $53(40.2)$ & $53(40.2)$ & $47(35.6)$ & \\
\hline Strongly agree & $64(16.2)$ & $25(18.9)$ & $25(18.9)$ & $22(16.7)$ & \\
\hline
\end{tabular}

Significantly difference between ethnic groups at ${ }^{*} p<0.05$ and ${ }^{* *} p<0.01$, tested using Chi-square test.

Table 5. Scores for barriers of breakfast consumption among subjects

\begin{tabular}{|c|c|c|c|c|c|}
\hline \multirow{2}{*}{ Variables } & \multicolumn{4}{|c|}{ Means \pm standard deviation } & \multirow{2}{*}{$p$-value } \\
\hline & Overall $(n=396)$ & Malay $(n=132)$ & Chinese $(n=132)$ & Indian $(n=132)$ & \\
\hline Class started very early in the morning & $2.71 \pm 0.98$ & $2.80 \pm 0.91$ & $2.55 \pm 1.00$ & $2.79 \pm 1.01$ & 0.06 \\
\hline Limited choice of breakfast & $2.68 \pm 0.91$ & $2.53 \pm 0.93$ & $2.86 \pm 0.85$ & $2.66 \pm 0.93$ & 0.13 \\
\hline Not enough time & $2.62 \pm 0.84$ & $2.73 \pm 0.87$ & $2.65 \pm 0.76$ & $2.49 \pm 0.89$ & 0.07 \\
\hline Food is not palatable & $2.38 \pm 0.86$ & $2.30 \pm 0.85$ & $2.48 \pm 0.80$ & $2.36 \pm 0.93$ & 0.19 \\
\hline High cost of breakfast & $2.35 \pm 0.91$ & $2.52 \pm 0.94^{\mathrm{a}}$ & $2.27 \pm 0.83^{\mathrm{b}}$ & $2.27 \pm 0.92^{\mathrm{b}}$ & $0.03^{*}$ \\
\hline Not feeling hungry & $2.18 \pm 0.94$ & $2.31 \pm 0.92$ & $2.07 \pm 0.94$ & $2.16 \pm 0.96$ & 0.12 \\
\hline No appetite & $2.18 \pm 0.94$ & $2.27 \pm 0.89$ & $2.10 \pm 0.97$ & $2.17 \pm 0.96$ & 0.34 \\
\hline Less of readily available food & $2.15 \pm 0.87$ & $2.09 \pm 0.84$ & $2.22 \pm 0.87$ & $2.14 \pm 0.91$ & 0.48 \\
\hline Uncomfortable being watch during eating & $1.67 \pm 0.82$ & $1.66 \pm 0.87$ & $1.64 \pm 0.68$ & $1.70 \pm 0.91$ & 0.82 \\
\hline Eating breakfast will cause obesity & $1.62 \pm 0.68$ & $1.58 \pm 0.68$ & $1.67 \pm 0.65$ & $1.64 \pm 0.72$ & 0.55 \\
\hline Total score & $22.55 \pm 4.35$ & $22.77 \pm 4.06$ & $22.51 \pm 4.39$ & $22.37 \pm 4.60$ & 0.75 \\
\hline
\end{tabular}

a,bDifferent alphabet in the same column shows a significant difference between ethnic groups at ${ }^{*} p<0.05$, tested using analysis of variance. 
This study has several strengths. Primarily, this study specifically studied the KAP and barriers to breakfast consumption. Previous studies mostly focused on the prevalence of breakfast skipping and its relation to BMI. This study also used a larger sample of participants than all but one (Moy et al., 2009) of the previous studies. Additionally, the ethnicities and gender ratio of subjects were also equal to avoid potential bias and generalize the findings. However, it also has some limitations. This study implemented a cross-sectional design, which limits us to establish causal relationships between the variables studied. Additionally, the student population was merely from one university only, which could limit the ability to represent students from other universities. Data on the patterns, KAP, and barriers of breakfast consumption were selfreported by the subjects, which depended on their memory and honesty in answering the questions. Therefore, the accuracy of the given information is not fully known. Nevertheless, the questionnaires were validated before the data collection. Additionally, data on the nutritional intake and quality of the breakfasts were not quantified in this study. A larger or longitudinal study aiming to explore how these parameters related to nutritional status and financial situation of the subjects, which now has been identified as a barrier among the Malay are needed and would be of value to breakfast consumption studies among the Malaysian population.

\section{CONCLUSION}

It can be concluded that Chinese students had the most frequent breakfast per week and had high KAP scores compared to Malay and Indian students. Students generally had good knowledge about breakfast consumption, but still unable to practice it accordingly particularly among the Malay. In addition to financial constraints, practicing unhealthy eating behaviors and food choices are among the factors that influenced breakfast consumption. Healthy eating awareness campaigns, education, and interventions should be reinforced particularly for first-year students. Additionally, policies that focus on providing healthy food and affordable food price in university cafeterias, and implementing a free food bank for low-income students are among the ways that could be done to address barriers and encourage behavioral changes towards optimizing breakfast consumption and subsequently practicing a healthy lifestyle.

\section{ACKNOWLEDGEMENTS}

The authors would like to express their appreciation to all subjects who had participated in this study Department of Food Science and, Faculty of Science and Technology for their supports.

\section{REFERENCES}

Alves, R.F. \& Precioso, J.A.G. 2020. Knowledge, attitude and practice on healthy diet among university students in Portugal. International Journal of Nutrition Sciences, 5(2): 90-97.

Awang Damit, N.A.D., Rahman, H.A. \& Ahmad, S.R. 2019. Breakfast intake habits among Universiti Brunei Darussalam Students. Pakistan Journal of Nutrition, 18: 817-823.

Ballon, A., Neunschwander, M. \& Schlesinger, S. 2019. Breakfast skipping is associated with increased risk of type 2 diabetes among adults: A systematic review and meta-analysis of prospective cohort studies. The Journal of Nutrition, 149(1): 106-113.

Bede, F., Cumber, S.N., Nkfusai, C.N., Venyuy, M.A., Ijang, Y.P., Wepngong, E.N. \& Kien, A.T.N. 2020. Dietary habits and nutritional status of medical school students: the case of three state universities in Cameroon. The Pan African Medical Journal, 35: 15.

Brandley, E.T. \& Holton, K.F. 2020. Breakfast positively impacts cognitive function in college students with and without ADHD. American Journal of Health Promotion, 34(6): 1-4.

Cebirbay, M.A., Aktas, N. \& Calderoni, M. 2011. Determination of breakfast habits and knowledge of foreign undergraduates studying at Selcuk University in Turkey. Progress in Nutrition, 4: 276-285.

Chawla, R., Emy, K., Singh, H.K.J. \& Razak, A.W.A. 2019. Role of breakfast, BMI and English language proficiency on academic performance of undergraduate dental students: a crosssectional study. British Journal of Medical \& Health Sciences, 1(3): 56-68.

Chen, H., Zhang, B., Ge, Y., Shi, H., Song, S., Zue, W., Li, J., Fu, K., Chen, X. \& Tian, L. 2020. Association between skipping breakfast and risk of cardiovascular disease and all-cause mortality: A meta-analysis. Clinical Nutrition, 39: 29822988.

Chin, Y.S. \& Mohd Nasir, M.T. 2009. Eating behaviors among female adolescents in Kuantan District, Pahang, Malaysia. Pakistan Journal of Nutrition, 8(4): 425-432. 
Das, B.M. \& Evans, E.M. 2014. Understanding weight management perceptions in first-year college students using the health belief model. Journal of American College Health, 62(7): 48897.

El Ansari, W., Stock, C. \& Mikolajczyk, R.T. 2012. Relationship between food consumption and living arrangements among university students in four European countries - A cross-sectional study. Nutrition Journal, 11: 28.

Fayet-Moore, F., McConnell, A., Tuck, K. \& Petocz, P. 2017. Breakfast and breakfast choice and its impact on nutrient and sugar intakes and anthropometric measures among a nationally representative sample of Australian Children and adolescents. Nutrients, 9(10): 1045.

Gaal, S., Kerr, M.A., Ward, M., McNulty, H. \& Livingstone, B.E. 2018. Breakfast consumption in the UK: patterns, nutrient intake and diet quality. A study from the International Breakfast Research Initiative Group. Nutrients, 10(8): 999.

George, D. \& Mallery, P. 2003. SPSS for Windows Step by Step: A simple guide and references. 11.0 update $\left(4^{\text {th }}\right.$ ed.) Boston: Allyn \& Bacon.

Hearst, M.O., Shanafelt, A., Wang, Q., Leduc, R. \& Nanney, M.S. 2016. Barriers, benefits and behaviors related to breakfast consumption among rural adolescents. Journal of School Health, 86(3): 187-194.

Isa, K.A.M. \& Masuri, M.G. 2011. The association of breakfast consumption habit, snacking behavior and body mass index among university students. American Journal of Food and Nutrition, 1(2): 55-60.

Javaid, Q. 2020. Breakfast and academic performance among college and university students: review of the available literature. International Archives of Biomedical and Clinical Research, 6(2): 1-6.

Krejcie, R.V. \& Morgan, D.W. 1970. Determining sample size for research activities. Educational and Psychological Measurement, 30: 607-610.

Kutty, N.A.M., Tin, Y.R., Chiang, V.H.Q.C. \& Zhi, W.Y. 2015. Association of dietary habits and body mass index among university students in Malaysia: a cross-sectional study. IOSR Journal of Nursing and Health Science, 4(5): 78-85.

Lupi, S., Bagordo, F., Stefanati, A., Grassi, T., Piccinni, L., Bergamini, M. \& Donno, A.D. 2015. Assessment of lifestyle and eating habits among undergraduate students in northern Italy. Ann $1^{\text {st }}$ Super Sanita, 51(2): 154-161.

Ma, X., Chen, Q., Pu, Y., Guo, M., Jiang, Z., Huang, W., Long, Y. \& Xu, Y. 2020. Skipping breakfast is associated with overweight and obesity: a systematic review and meta-analysis. Obesity Research and Clinical Practice, 14(1): 1-8.
Mansouri, M., Hasani-Ranjbar, S., Yaghubi, H., Rahmani, J., Tabrizi, Y.M., Keshtkar, A., Varmaghani, M., Sharifi, F. \& Sadeghi, O. 2020. Breakfast consumption patterns and its association with overweight and obesity among university students: a population-based study. Eating and Weight Disorders - Studies on Anorexia, Bulimia and Obesity, 25: 379-387.

Mat Ludin, A.F.M., Li, L.S., Ting, H.M., Lin, C.H., Wan Ya, W.N., Kamarul Zaman, M., Gunasekaran, D.D., Kamararudin, N.I., Lim, M.L., Abdul Razak, N., Tan, C.Y., Saidin, N., Allam, R., Chong, G.Y. \& Chieng, T.M. 2016. Factors affecting breakfast consumption and its association with academic performance among undergraduates. Jurnal Intelek, 10(2): 1-6.

Mathiyalagen, P., Yadav, D., Anandaraj, R., Vasudevan, K., Sundar, B., Priyadharsini, R., Meerambika, M. \& Jin, J.O. 2019. Breakfast consumption habit and its impact on nutrient intake and nutritional status of medical undergraduates. Progress in Nutrition, 21(3): 570-6.

Min, C.Y., Noh, H.Y., Kang, Y.S., Sim, H.J., Baik, H.W., Song, W.O., Yoon, J.H., Park, Y.H. \& Joung, H.J. 2014. Breakfast patterns are associated with metabolic syndrome in Korean adults. Nutrition Research Practise, 5(1): 61-67.

Moreno, J.P., Crowley, S.J., Alfano, C.A., Hannay, K.M., Thompson, D. \& Baranowski, T. 2019. Potential circadian and circannual, rhythm contributions to the obesity epidemic in elementary school age children. International Journal of Behavioral Nutrition and Physical Activity, 16: 25.

Moy, F.M., Johari, S., Ismail, Y., Mahad, R., Tie, F.H. \& Wan Ismail, W.A. 2009. Breakfast skipping and its associated factors among undergraduates in a public university in Kuala Lumpur. Malaysian Journal of Nutrition, 15(2): 165-74.

Najwa, N. \& Appukutty, M. 2018. Breakfast consumption association with body status and physical activity among female university students. Malaysian Journal of Movement, Health \& Exercise, 7(2): 93-106.

National Health and Morbidity Survey 2019. Technical Report - Volume 1. NCDs - NonCommunicable Diseases: Risk factors and other health problems. National Institutes of Health NIH). Ministry of Health Malaysia.

Nishiyama, M., Suzuki, E., Hashimoto, M., Takaoka, N., Inaba, M., Tadokoro, N., Kumakura, M., Furuichi, T. \& Kamikawa, Y. 2013. Skipping breakfast is associated with academic achievement, unhealthy behaviors, and sense of coherence among medical students. Dokkyo Journal of Medical Sciences, 40(1): 47-54. 
Pedersen, T.P., Holstein, B.E., Flachs, E.M. \& Rasmussen, M. 2013. Meal frequencies in early adolescence predict meal frequencies in late adolescence and early adulthood. BMC Public Health, 13: 445.

Pendergast, F.J., Livingstone, K.M., Worsley, A. \& McNaughton, S.A. 2016. Correlates of meal skipping in young adults: a systematic review. The International Journal of Behavioral Nutrition and Physical Activity, 13: 125.

Pengpid, S. \& Peltzer, K. 2020. Skipping breakfast and its association with health risk behaviour and mental health among university students in 28 countries. Diabetes, Metabolic Syndrome and Obesity: Targets and Therapy, 13: 2889-2897.

Pereira, J.L., de Castro, M.A., Hopkins, S., Gugger, C., Fisberg, R.M. \& Fisberg, M. 2018. Prevalence of consumption and nutritional content of breakfast meal among adolescents from the Brazilian National Dietary Survey. Jornal de Pediatria, 94(6): 630-641.

Perumal, N., Cole, D.C., Ouedraogo, H.Z., Sindi, K., Loechi, C., Low, J., Levin, C., Kiria, C., Kurji, J. \& Oyunga, M. 2013. Health and nutrition knowledge, attitudes and practices of pregnant women attending and not-attending ANC clinics in Western Kenya: a cross-sectional analysis. BMC Pregnancy Childbirth, 13: 146.

Ramsay, S.A., Bloch, T.D., Marriage, B., Shriver, L.H., Spees, C.K. \& Taylor, C.A. 2018. Skipping breakfast is associated with lower diet quality in young US children. European Journal of Clinical Nutrition, 72(4): 548-556.

Reutrakul, S., Hood, M.M., Crowley, S.J., Morgan, M.K., Teodori, M. \& Knutson, K.L. 2014. The relationship between breakfast skipping, chronotype, and glycemic control in type 2 diabetes. Chronobiology International, 31(1): 64-71.

Sangwanna, S. \& Thongprasert, C. 2019. Breakfast skipping habit effect to energy and nutrients intake among university students. International Journal of Advances in Science Engineering and Technology, 7(2): 67-70.

Sukkrachang, K. 2017. Knowledge, attitude and breakfast consumption behaviors of upper elementary students in Muang District, Songkla. in: The International Conference on Graduate Students' Research Work, pp. 1-11.

Sundaram, D., Ghazi, H.F. \& Elnajeh, M. 2018. Breakfast, food consumption pattern and nutritional status among private university students in Shah Alam, Selangor. International Journal of Advanced Community Medicine, 1(1): 19-22.
Tarmizi, S.F.M., Daud, N.M. \& Rahman, H.A. 2020. Malaysian ready-to-eat cooked dishes: consumption patterns among adults and nutrient composition of selected highly consumed dishes. Malaysian Applied Biology, 49(5): 6170.

Tok, C.Y., Ahmad, S.R. \& Koh, D.S.Q. 2018. Dietary habits and lifestyle practices among university students in Universiti Brunei Darussalam. The Malaysian Journal of Medical Sciences, 25(3): 56-66.

Torrente, X.D. \& Scarpelli, D.Q. 2020. Dietary patterns of breakfast consumption among Chilean University students. Nutrients, 12(2): 552.

Wan Azdie, M.A.B., Ismail, S., Sidek, S. \& Rahman, R.A. 2019. Prevalence and factors affecting food insecurity among university students in Pahang, Malaysia. Malaysian Journal of Nutrition, 25(1): 59-67.

Wicherski, J., Schlesinger, S. \& Fischer, F. 2021. Association between breakfast skipping and body weight - a systematic review and metaanalysis of observational longitudinal studies. Nutrients, 13(1): 272.

World Health Organization (WHO). 1995. WHO Technical Report Series 854. World Health Organization, Geneva.

Yahya, N.F.S., Daud, N.M., Makbul, I.A.A. \& Aziz, Q.A.S.A. 2021. Association of calcium intake, lactose intolerance and physical activity with bone health status assessed via quantitative ultrasound among young adults of a Malaysian university. Archives of Osteoporosis, 16(1): 14.

Yap, S.Y., Aziz, Y., Asma', A. \& Yusof, H.M. 2019. Ethnic variation in osteoporosis risk factors: dietary calcium, vitamin D intake and body mass index (BMI). Food Research, 3(6): 741-748.

Yokoyama, Y., Onishi, K., Hosoda, T., Amano, H., Otani, S., Kurozawa, Y. \& Tamakoshi, A. 2016. Skipping breakfast and risk of mortality from cancer, circulatory diseases and all causes: Findings from the Japan Collaborative Cohort Study. Yonago Acta Medica, 59(1): 55-60.

Zeron-Rugerio, M.F., Hernaez, A., Porras-Loaiza, A.P., Cambras, T. \& Izquierdo-Pulido, M. 2019. Eating jet lag: a marker of the variability in meal timing and its association with body mass index. Nutrients, 11(12): 2980. 